\title{
Water Supply Improvement and Health Promotion Campaigns in Rural Areas - China, 1949-2020
}

\author{
Hongxing Li ${ }^{1, *} ;$ Alasdair Cohen ${ }^{2}$; Lin Lin ${ }^{3}$; Xiaoxiao Zhang ${ }^{1}$; Rong Zhang ${ }^{1, *}$
}

In the 1950s, shortly after the founding of the People's Republic of China (PRC), the central government created the Patriotic Health Campaign (PHC) in order to standardize and disseminate healthfocused educational materials intended to control and prevent infectious diseases (1). "Water improvement", meaning measures aimed at providing safe drinking water for households in China, was an important part of the PHC. After 60 years of water improvement policies, programs, and investments, the rural water supply sanitation and hygiene in China has improved dramatically, and water-related diseases no longer negatively impact the rural population as they once did. In addition to improvements related to the quantity and quality of the rural water supply, water improvement programs also promoted improved hygiene, sanitation, and other health-related behaviors among rural households. Together, such initiatives have improved the quality of life and the health of hundreds of millions of rural residents, while also contributing to economic and social advancement across rural China (2). The purpose of this article is to describe how the PHC served as a foundation for the expansion and improvement of drinking water supply in rural China, and to summarize the key programs, projects, and initiatives that followed over the last 60 years.

\section{BACKGROUND}

China is a large, still developing country with a total rural population of 564 million, accounting for $40.4 \%$ of the country's total population as of 2018/2019 (3). At the time of the country's founding in 1949, nearly all rural residents collected their drinking water from rivers, lakes, ponds, and relatively shallow hand-dug wells, as they had done for generations before. Not surprisingly then, early surveillance studies revealed a relatively high incidence of various gastrointestinal infections and other water-related endemic diseases (4). The associated burden of disease threatened people's health and hindered socioeconomic development in rural areas. This dynamic wherein "poverty begets disease, and disease begets poverty" was widespread prior to the implementation of China's water improvement programs and other health-focused campaigns in rural areas.

Central to the PHC was an emphasis on healthfocused education and the construction of healthrelated infrastructure. Importantly, the PHC also fostered improved collaboration among government agencies at different levels of governance (e.g., national, provincial, county levels) and between agencies with overlapping or complementary mandates to improve the well-being and health of rural households. As a result, PHC initiatives were successful in reaching the rural population and encouraging them to adopt improved health-related attitudes and behaviors (1).

\section{RURAL WATER IMPROVEMENT IN PRACTICE}

Since the founding of the PRC, China's government recognized the importance of rural water supply and sanitation and sought to promote the development of improved water and sanitation infrastructure and management (5). Water improvement actions were specifically embedded in China's National Social and Economic Five-Year Development Plans as early as 1986.

\section{Water Quality Improvement}

In broad terms, China's rural water supply development evolved over the course of four stages as summarized in Table 1. As a consequence of these decades of deliberate and planned efforts - especially the implementation of the Rural Water Supply Five Year Plans starting in 2005 - more than 520 million rural residents, including more than 47 million rural schoolteachers and students, now have access to some form of piped water supply. By 2019, the proportion of the rural population covered by centralized 
TABLE 1. The four primary stages of rural water supply, time period, and primary water improvement programs in China, 1949-2020.

\begin{tabular}{|c|c|c|c|}
\hline Stage & Period & Primary water improvement programs & Additional Details \\
\hline $\begin{array}{l}\text { Initial development and } \\
\text { improvement of } \\
\text { decentralized water supply }\end{array}$ & $\begin{array}{l}1949 \text { to early } \\
1980 \text { s }\end{array}$ & $\begin{array}{l}\text { Basic water improvement measures (e.g., } \\
\text { building well protection platforms and/or } \\
\text { covers, separating drinking water sources } \\
\text { used for people and livestock) }\end{array}$ & $\begin{array}{l}\text { Most measures were improvements to existing } \\
\text { water supply systems; reservoirs, irrigation } \\
\text { infrastructure, and some new drinking water } \\
\text { facilities were also constructed during this period. }\end{array}$ \\
\hline $\begin{array}{l}\text { Construction of centralized } \\
\text { water supply infrastructure }\end{array}$ & $\begin{array}{l}\text { Early } 1980 \text { s } \\
\text { to early } \\
2000 \text { s. }\end{array}$ & $\begin{array}{l}\text { - International Drinking Water Supply and } \\
\text { Sanitation Decade (7) } \\
\text { - The Rural People/Livestock Drinking Water } \\
\text { Program } \\
\text { - China Rural Water and Sanitation Program } \\
\text { (supported by the World Bank and Asian } \\
\text { Development Bank). }\end{array}$ & $\begin{array}{l}\text { The central government creates long-term } \\
\text { strategies and plans for rural water supply, } \\
\text { including the establishment of national water } \\
\text { standards, and collaborates with international } \\
\text { agencies. }\end{array}$ \\
\hline $\begin{array}{l}\text { Rapid development of } \\
\text { drinking water supply in } \\
\text { rural areas }\end{array}$ & 2000 to 2015 & $\begin{array}{l}\text { - Rural Drinking Water Emergency Project } \\
\text { Plan } \\
\text {-Rural Drinking Water } 11^{\text {th }} \text { Five-Year Plan } \\
\text { - Rural Drinking Water } 12^{\text {th }} \text { Five-Year Plan }\end{array}$ & $\begin{array}{l}\text { Government agencies at all levels emphasize the } \\
\text { importance of rural water supply, which is also } \\
\text { incorporated into the National Socioeconomic } \\
\text { Development Plan. These efforts are accompanied } \\
\text { by a focus on sustainable development goals. }\end{array}$ \\
\hline $\begin{array}{l}\text { The consolidation, } \\
\text { improvement, and } \\
\text { promotion of rural water } \\
\text { supply }\end{array}$ & $\begin{array}{l}2015 \text { to } \\
\text { present }\end{array}$ & $\begin{array}{l}\text { - Rural Drinking Water Supply Consolidation } \\
\text { and Improvement Plan }\end{array}$ & $\begin{array}{l}\text { Focus on upgrading existing rural water supply } \\
\text { projects and improving management and operation } \\
\text { systems to further expand piped water supply in } \\
\text { rural areas, with an emphasis on consistent } \\
\text { compliance with national water supply and quality } \\
\text { standards. }\end{array}$ \\
\hline
\end{tabular}

drinking water treatment and distribution had reached $82 \%(\circlearrowleft)$.

\section{Establishment and Improvement of the National Rural Drinking Water Quality Monitoring Network}

Furthermore, the National Rural Drinking Water Quality Monitoring Network (NRDWMN) was created in the 1990s and included Rural Drinking Water Projects from Five-Year Plans through 2003 (8). From 2004 to 2007, the NRDWMN was incorporated into the National Health Risk Factor Monitoring System, an internet-based information system which covers all provincial-level administrative divisions (PLADs), cities, and counties. By the end of 2019, data collected for the NRDWMN covered $>98 \%$ of the townships in China. As one of China's largest public health monitoring systems, NRDWMN provides information related to water and sanitation management and serves to help safeguard drinking water safety around the country.

\section{From Water Quality Monitoring to Water Quality Management}

To improve the management and quality of rural drinking water supply, China has expanded from a focus on water quality testing to a more holistic water quality management model based on strengthening preventive measures across the water supply process. In recent years, several PLADs have started to use Water Safety Plans (WSP), a drinking water quality management approach and toolset promoted by the World Health Organization's (WHO) Guidelines for Drinking Water Quality (9). The WSP is a comprehensive drinking water management framework which encompasses all steps of water supply from source to consumer. Although the implementation of WSPs in China is not yet widespread, the Ministry of Health (now called the National Health Commission, NHC) proposed Technical Rules for Sanitary Evaluation (TRSE) (for rural drinking water safety) in 2008 which were in developed in part based on WSP principles (10). Much like the WSPs rationale, the TRSE was designed to support the systematic identification of potential water quality risks in water systems and to help establish control measures to responsibly manage such risks (11).

\section{EXPANDING ACCESS TO SAFE WATER AND IMPROVING HEALTH IN RURAL AREAS}

From 1990 to 2012, close to 500 million people in China received access to improved sources of drinking water (12). Over the same period (1990 to 2013), the age-standardized death rate from (mostly water-related) diarrheal disease decreased by $95 \%$ (13). Alongside the rapid expansion of piped water access in rural China, 
the incidence of reportable water-associated infectious diseases also decreased dramatically. For example, typhoid and paratyphoid dropped from a rate of $10.32 / 100,000$ population in 1990 to $0.66 / 100,000$ in 2019 , the incidence of dysentery decreased from $127.44 / 100,000$ in 1990 to $5.81 / 100,000$ in 2019, and the incidence of viral hepatitis A decreased from $7.37 / 100,000$ in 2003 to $1.38 / 100,000$ in 2019 (Figure 1).

Since 2005, the central government has implemented the 2005-2006 Plan for Rural Drinking Water Safety Emergency Projects, the $11^{\text {th }}$ and $12^{\text {th }}$ Five-Year National Plans for Rural Drinking Water Safety Projects, and the $13^{\text {th }}$ Five-Year Plan for National Rural Drinking Water Safety Consolidation and Promotion Projects - all of which also prioritized efforts to address areas with endemic fluorine and arsenic exposures. These projects adopted a variety of technical and management approaches, including fluorine and arsenic remediation, which in turn improved the drinking water quality dramatically in areas historically suffering from arsenicosis and fluorosis. Consequently, the number of patients with dental fluorosis decreased from 21.0 million in 2003 to 1.3 million in 2018 , a decrease of $93.8 \%$. The number of patients with skeletal fluorosis decreased from 1.3 million in 2003 to 0.09 million in 2018, a decrease of $93.1 \%$.
The main experiences of rural water supply development in China could be summarized as the following: 1) The government attached great importance to rural water supply development in addition to the wide participation of the pubic; 2) The '3-in-1' concept combining rural water improvement, sanitation, and health education had promoted the improvement of water and sanitation infrastructure, as well as popularization of health knowledge.

\section{CHALLENGES AND PROSPECTS}

Water improvement programs in China have evolved considerably over the last 60 or so years and rural water supply infrastructure has been improved significantly. However, considering China's vast size, varied topography, regional disparities in the distribution of natural water resources, and other constraints, the challenge of addressing all of China's drinking water related problems remains a long-term and dynamic one.

During the $13^{\text {th }}$ Five-Year Plan period, enormous effort will be made to boost capacity for further expanding safe drinking water access in rural China. The country will strive to move towards the equalization of rural-urban water supply by supplementing, upgrading, and establishing new rural networks alongside existing drinking water projects. At

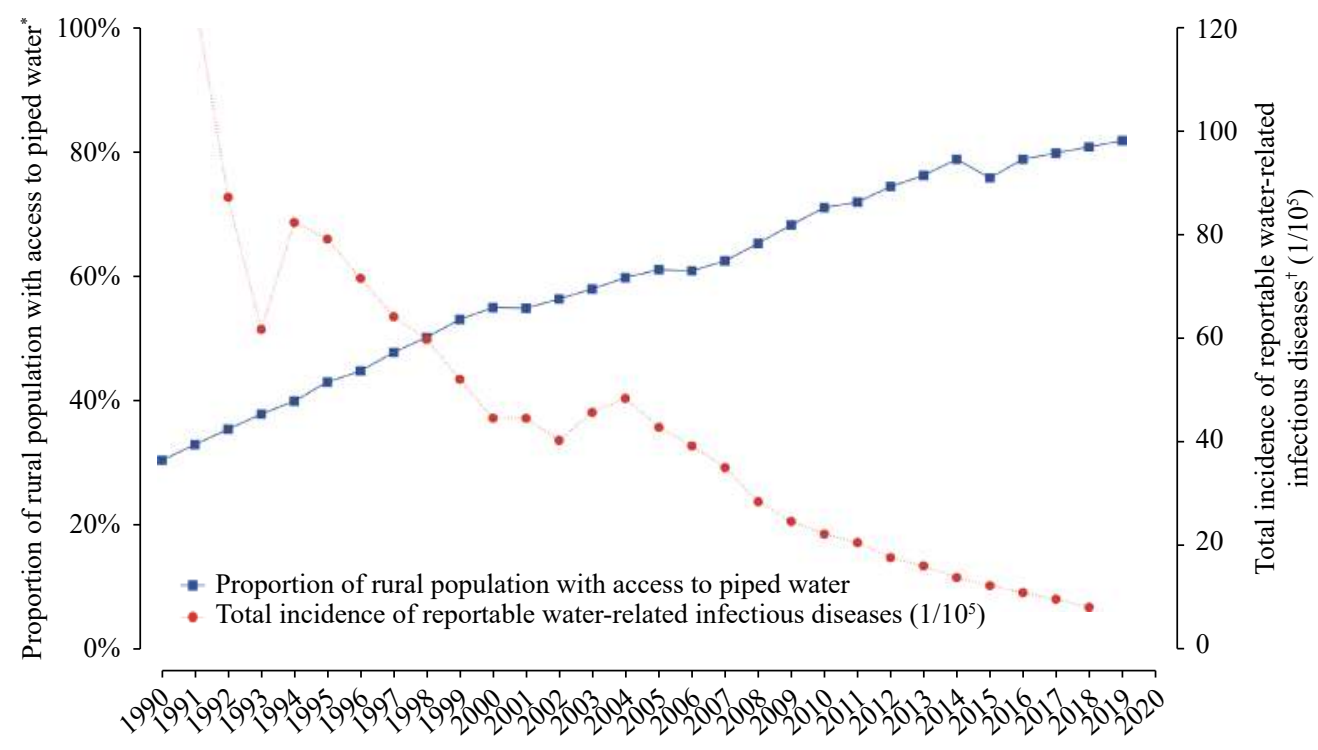

FIGURE 1. Proportion of rural population with access to piped water and mean incidence of reportable water-related infectious diseases in china: 1990 to 2020.

* Data source: National Health and Family Statistical Yearbook; Water Conservancy Development Bulletin.

† Data source: National Health and Family Statistical Yearbook; including typhoid fever, paratyphoid fever, dysentery, hepatitis $A$. 
the time of writing of this article (towards the end of 2020), the coverage ratio of centralized water supply projects in rural areas is estimated to be $87 \%$, and the proportion of the country's rural population with access to piped water supply is estimated to exceed $82 \%$ (G).

Looking to the years ahead, in addition to infrastructure construction, the management of water supply quality needs to be strengthened further. Comprehensive and routine evaluation of rural drinking water supply management via the use of WSPs should be expanded to more rural water supply systems (11). In addition to continued progress in water supply infrastructure and management, health education and health behavior promotion programs remain a crucial element of water improvement, just as they were during the early years of the PHC.

doi: $10.46234 / \mathrm{ccdcw} 2021.002$

\# Corresponding authors: Hongxing Li, lihx@ncrwstg.chinacdc.cn; Rong Zhang, zhangrong@chinacdc.cn.

\begin{abstract}
National Center for Rural Water Supply Technical Guidance, Chinese Center for Disease Control and Prevention, Beijing, China;

${ }^{2}$ Department of Population Health Sciences \& the Public Health Program, Virginia Polytechnic Institute \& State University (Virginia Tech), Blacksburg, VA, USA; ${ }^{3}$ Office for public health management, Chinese Center for Disease Control and Prevention, Beijing, China.
\end{abstract}

Submitted: November 18, 2020; Accepted: December 29, 2020

\section{REFERENCES}

1. Li ZD. Review of patriotic health campaign. Beijing Dangshi 2010(3): 25 - 30. http://www.cnki.com.cn/Article/CJFDTotal-BJDY201003009. htm. (In Chinese).

2. Ministry of Water Resources, People's Republic of China. Rural water supply in China. Beijing (China): Ministry of Water Resources, People's
Republic of China. http://www.mwr.gov.cn/english/. [2020-12-29].

3. National Bureau of Statistics. China statistical yearbook 2019. Beijing: China Statistics Press. 2019. http://www.stats.gov.cn/tjsj/ndsj/2019/ indexch.htm. (In Chinese).

4. Wei CY. Basic situation and prevention countermeasures of intestinal infectious diseases in China. J Chin Phys 2001;29(6):6 - 8. http://dx.doi.org/10.3969/j.issn.1008-1089.2001.06.004. (In Chinese).

5. Li HX, Zhang Q, Li WW, Luo Q, Liu KT, Tao Y. Spatial analysis of rural drinking water supply in China. Water Policy 2015;17(3):441 53. http://dx.doi.org/10.2166/wp.2014.193.

6. Zhang YL. The rate of centralized water supply reached $87 \%$ and the penetration rate of tap water reached $82 \%$ in rural areas, China. China.org.cn, 2020 Apr 14. http://news.china.com.cn/txt/2020-04/14/ content_75931127.htm. [2020-12-29]. (In Chinese).

7. World Health Organization. Community Water Supply and Sanitation Unit. International drinking water supply and sanitation decade: project and programme information system. Rev. ed. Geneva: World Health Organization. 1983. https://apps.who.int/iris/handle/10665/61592.

8. Zhang R. Current situation and countermeasures of rural drinking water quality monitoring in China. In: Proceedings of Paper Collection of Annual Meeting of China Science and Technology Association 2017. Wuhan, China: China Association for Science and Technology, China Instrument Society, China Electronics Society, China Society of Electrical Engineering, China Railway Society. 2017. http://d. wanfangdata.com.cn/conference/6441774. (In Chinese).

9. WHO. Guidelines for Drinking-Water Quality. 3th ed. Geneva: World Health Organization. 2004. https://www.who.int/water_sanitation_ health/publications/gdwq3/en/. [2020-12-29].

10. Office of the National Patriotic Health Campaign Committee. Notice on printing and distributing the technical rules for hygienic evaluation of rural drinking water safety projects (for trial Implementation). Beijing (China): Government of the People's Republic of China; 2008 http://www.gov.cn/gzdt/2008-05/10/content_966400.htm. [2020-12-29]. (In Chinese).

11. Li HX, Smith CD, Cohen A, Wang L, Li Z, Zhang R, et al. Implementation of water safety plans in China: 2004-2018. Int J Hyg Environ Health 2020;223(1):106 - 15. http://dx.doi.org/10.1016/j. ijheh.2019.10.001.

12. UNICEF, WHO. Progress on drinking water and sanitation: 2014 update. New York: UNICEF, WHO. 2014: 74. https://www.unicef. org/publications/index_73448.html.

13. Zhou MG, Wang HD, Zhu J, Chen WQ, Wang LH, Liu SW, et al. Cause-specific mortality for 240 causes in China during 1990-2013: a systematic subnational analysis for the Global Burden of Disease Study 2013. Lancet 2016;387(10015):251 - 72. http://dx.doi.org/10.1016/ S0140-6736(15)00551-6. 